\title{
Benign Ovarian Brenner Tumor
}

National Cancer Institute

\section{Source}

National Cancer Institute. Benign Ovarian Brenner Tumor. NCI Thesaurus. Code C4746.

A benign transitional cell neoplasm that arises from the ovary and is composed of a

fibrotic stroma and nests of transitional cells without evidence of atypia. There is no evidence of invasion. 